\title{
EFFECT OF COURTYARD ASPECT RATIO ON ANNUAL COOLING ENERGY OF HIGHRISE APARTMENT IN SURABAYA
}

\author{
Putri Melati Dewi ${ }^{1}$ | I Gusti Ngurah Antaryama*2 | Ima Defiana ${ }^{2}$
}

\footnotetext{
${ }^{1}$ Graduate Programme of Architecture, Institut Teknologi Sepuluh Nopember, Surabaya, Indonesia

${ }^{2}$ Department of Architecture, Design, and Planning, Institut Teknologi Sepuluh Nopember, Surabaya, Indonesia

\section{Correspondence}

*I Gusti Ngurah Antaryama, Department of Architecture, Design, and Planning, Institut Teknologi Sepuluh Nopember, Surabaya, Indonesia. Email:

andaivianaantaryama@arch.its.ac.id
}

\section{Present Address}

Gedung Teknik Arsitektur, Kampus ITS Sukolilo, Surabaya 60111, Indonesia

\begin{abstract}
Rapid development of high-rise apartments, which rely on mechanical cooling, would increase energy consumption. Courtyard existed in various geometries of a high-rise apartment in Surabaya as a result of useful layout configuration. The courtyard is one of the passive cooling strategies in vernacular building and is reported to reduce a building's energy consumption. The size of the courtyard affects the performance of the courtyard. In high-rise courtyard apartments in Surabaya, there is a wide variation of building width and length, affecting the courtyard aspect ratio. This paper investigates the result of annual cooling energy of different courtyard aspect ratio on five apartment geometries with courtyard: H Geometry, U Geometry, Double U Geometry, Double L Geometry, and Quadruple L Geometry. The method of this research is experimental research with simulation as a tactic. DesignBuilder by EnergyPlus is used as simulation tools in this research. The result reveals that a courtyard with an aspect ratio of 1:2 tends to perform better than a square courtyard. Elongating the courtyard of $\mathrm{H}$ and $\mathrm{U}$ Geometry would reduce the annual cooling energy in all orientations. Elongating the courtyard of Double U, Double L, and Quadruple L Geometries would reduce the annual cooling energy in northwestsoutheast orientation and increase annual cooling energy if the building is elongated alongside the northeast axis..
\end{abstract}

\section{KEYWORDS:}

Courtyard, High-Rise Apartment, Cooling Energy, Geometry 


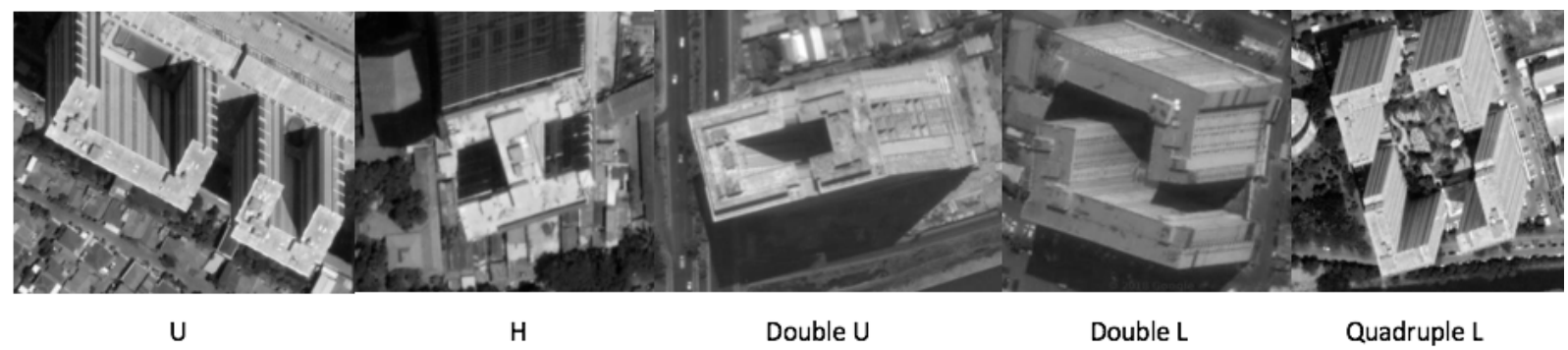

FIGURE 1 Five different geometries of high-rise apartments with courtyard in Surabaya.

\section{1 | INTRODUCTION}

It is reported by Colliers International Survey [1] a total of 33,414 new apartment units are expected to be completed in the next four years in Surabaya. According to the field Survey of Apartments in Surabaya, the average air temperatures inside the private apartment unit were generally higher than the outdoors under natural ventilation conditions only ${ }^{[2}$. Operating Air Conditioner in apartment units with a higher temperature than the surrounding environment would decrease the energy efficiency of an AC, thus increasing building energy consumption. A study conducted by Huda and Suheta ${ }^{[3]}$ about electricity usage in one of the high-rise apartments in Surabaya mentioned that Air Conditioner usage accounts for 49.9

According to Yeang ${ }^{[4]}$, building energy consumption is influenced by building form, orientation, and building volume to surface ratio. Solar radiation received by the building would result in building thermal performance and energy consumption. Different building shapes would have different exposure from solar radiation, thus affecting the building's thermal performance.

Among several high-rise apartments in Surabaya, an internal courtyard, or open space enclosed by surrounding walls, can be easily found. Lately, the courtyard has been a prominent design element in high-rise apartments due to the effective layout configuration and provision of open space for the building occupants. In the high-rise apartments of Surabaya, Courtyard is often functioned as an open recreational area for occupants, with a swimming pool and greenery.

Aldawould, A. [5] revealed that a building with a courtyard is energy-efficient in all climates, especially in the hot arid and hot, humid climates. The shading and ventilation effect is the courtyard's main function in a hot climate ${ }^{[5]}$. According to Hyde ${ }^{[6]}$, the courtyard proportion and design of envelopes surrounding the courtyard determine the courtyard performance. Two variables related to the size of the courtyard are courtyard height and courtyard aspect ratio. The courtyard's height usually determines the number of floor buildings surrounding the courtyard, whereas the courtyard aspect ratio is the proportion of courtyard width to length.

A study about courtyard aspect ratio in the hot arid region mentioned that a long rectangular courtyard would generate a lower cooling load and solar gain. Manioglu and Oral ${ }^{[7]}$ studied various courtyard width to length ratios (W/L) range from 0.2 to 2 on different building areas. Building with $100 \mathrm{~m} 2$ area generates lower cooling load and solar gain when courtyard W/L is 0.2 . On the other hand, buildings with a $200 \mathrm{~m} 2$ area generate lower cooling load and solar gain when courtyard W/L is 1.2 and 2 , respectively. A study about courtyard aspect ratio in temperate climate also mentioned that a longer courtyard would result in a lower cooling load because it could provide more shading ${ }^{[8]}$.

Studies about courtyard size related to its height and aspect ratio towards energy consumption have been conducted in a temperate and hot arid climate. Studies about this field are still limited in a warm and humid region. Studies about the courtyard in the warm and humid region are mainly about the courtyard's impact on ventilation and indoor temperatures. This research focuses on the courtyard aspect ratio of different high-rise apartments because there are several courtyard aspect ratios. In contrast, the height of high-rise apartments in Surabaya are almost similar. 


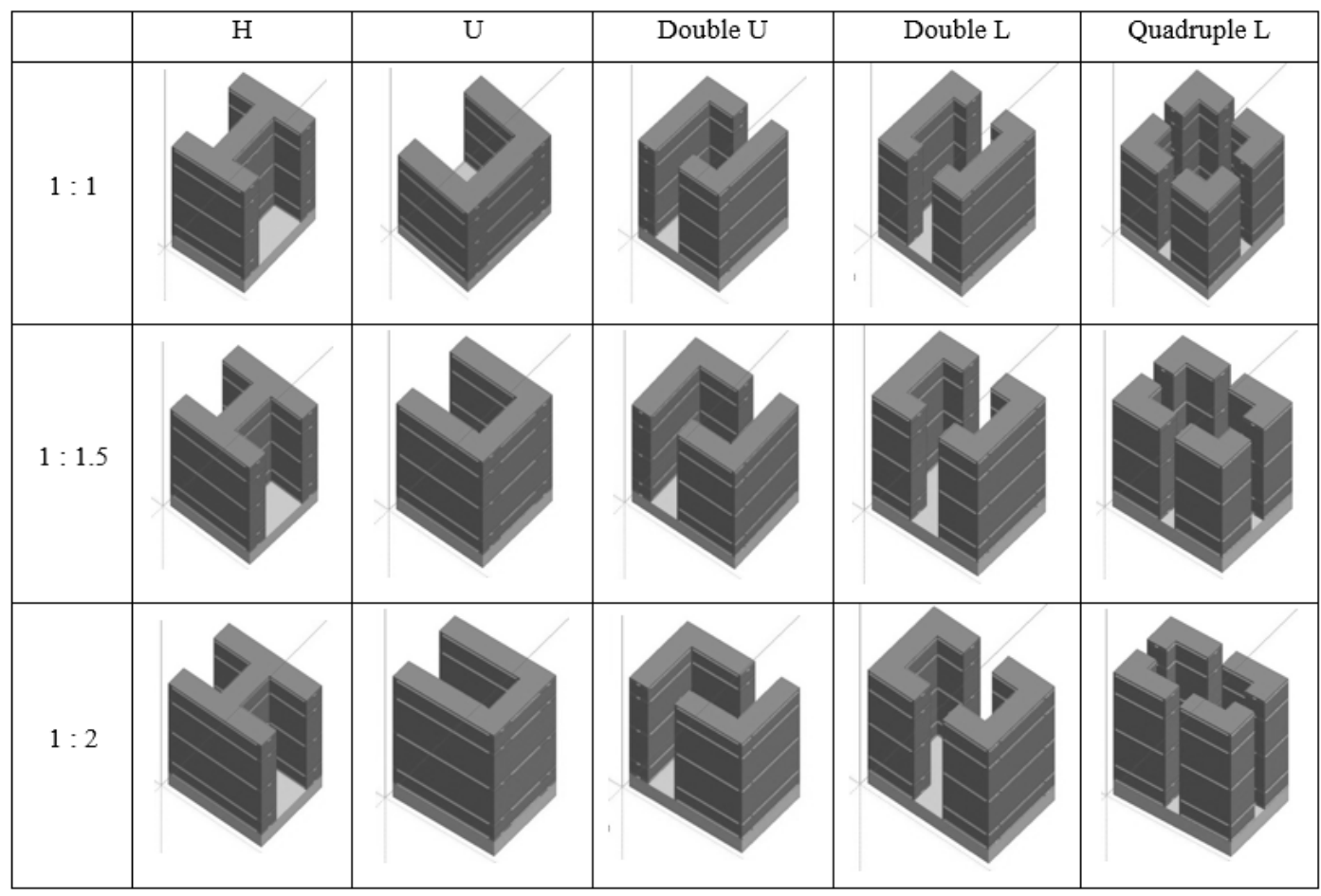

FIGURE 2 The model experiments of three different courtyard aspect ratio on five studied geometries of courtyard high rise apartments.

\section{2 | MATERIAL AND METHOD}

To investigate the impact of courtyard aspect ratio on cooling energy, a computer simulation using Design Builder by EnergyPlus is used. The method of this research is experimental research using simulation as a tactic. The courtyard aspect ratio that would be investigated in this research is 1:1,1:1.5, and 1:2 because the courtyard aspect ratio of a high-rise apartment in Surabaya range from 1:1 to 1:2. Three different courtyard aspect ratios would be applied to five different building geometries (see Fig 1) of high-rise apartments: H, U, Double U, Double L, and Quadruple L geometries (see Fig 2). These five geometries are found in the courtyard high-rise apartment of Surabaya. Later it would be simulated into three different orientations. Therefore, this research's independent variables are courtyard aspect ratio, building geometry, and building orientation.

The dependent variable of this research is as follows building annual cooling energy. Building cooling energy consumption would be measured through energy consumption per square meter annually $(\mathrm{kWh} / \mathrm{m} 2 / \mathrm{yr})$. A building's cooling energy contributes to overall building Energy Use Intensity (EUI), which accumulates various energy usage of a building, such as the energy required for heating and cooling, lighting, pump, hot water, and other electrical loads. In this research, internal heat gain is included in the variable control group to evaluate the pure impact of courtyard aspect ratio, building geometry, and orientation towards annual cooling energy. This research's main focus is the apartment units' cooling energy because they contribute the highest portion of cooling energy in a high-rise apartment. The layout of the model experiments is modeled according to the arrangement of floor consist of apartment units. Cooling energy for communal facilities usually located in the apartment's podium area is not considered in this research.

The model experiments are modeled after the real-life condition of high-rise apartments with courtyard, as seen in Fig 3 . These high-rise apartments have a building podium, and the courtyard area is located on top of the building podium. Detailed classification of the model experiments is explained in Table 1 and Table 2. The courtyard area is similar in different aspect ratios. The minimum distance of model experiments is based on the Ministry of Public Works Regulation (29/PRT/ M/2006), which stated that the minimum distance of two towers in one base with a window on both is $25 \mathrm{~m}$, as well as Ministry of Public Works Regulation (10/KTPS/ 2000) which stated that Minimum building distance higher than $40 \mathrm{~m}$ is $8 \mathrm{~m}$. As a result, the courtyard's 
TABLE 1 Control variables of the model experiments.

\begin{tabular}{ll}
\hline Control Variables & Model Experiment \\
\hline Courtyard Area & $1600 \mathrm{~m} 2$ Aspect Ratio $1: 1 \quad$ (40m x 40m) \\
& Aspect Ratio 1:1.5 (32.5m x 49m) \\
& Aspect Ratio $1: 1 \quad(28 \mathrm{~m} \times 57 \mathrm{~m})$ \\
& $30-$ story floors \\
Number of floors & $4-$ story podium \\
Number of podia & $14 \mathrm{~m}$ \\
Building thickness & $3 \mathrm{~m}$ \\
Floor to floor height & Lightweight concrete \\
Building Material & $30 \%$ \\
WWR & \\
\hline
\end{tabular}

TABLE 2 Detailed material input of the model experiment.

\begin{tabular}{ll}
\hline Building Element & Material \\
\hline Walls & $\begin{array}{l}\text { Lightweight concrete painted light } \\
\text { grey (exterior), painted white } \\
\text { (interior) } \\
120 \times 220 \mathrm{~cm} \text {, aluminum frame } \\
\text { painted white } 3 \mathrm{~mm} \text { of single clear } \\
\text { glass }\end{array}$ \\
Window & $\begin{array}{l}\text { tiles } 40 \text { creamy colored ceramic } \\
\text { thoor }\end{array}$ \\
& White painted plastered ceiling \\
& Wooden door with a dimension of \\
Ceiling & $2.1 \times 0.8 \mathrm{~m}$. \\
\hline
\end{tabular}

Building Geometry Courtyard Aspect Ratio

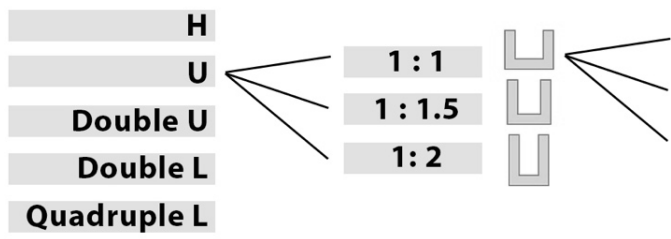

Orientation

North - South

Northwest - Southeast

West - East

FIGURE 3 The matrix diagram of the experimental research.

minimum width is $28 \mathrm{~m}$, when the courtyard aspect ratio is 1:2. The gap distance between two towers of Double $\mathrm{U}$, Double $\mathrm{L}$, and Quadruple L Geometries is $10-20 \mathrm{~m}$.

The climate data of Surabaya used for running the simulation is obtained from the Juanda International Airport. To match the software requirements, the climate data input in the form of EPW (EnergyPlus Weather Data) format. The climate data used in this simulation is hourly climate data for the year 2017.

\section{3 | RESULTS AND DISCUSSION}

\subsection{Impact on Each Geometry}

Fig 4 shows the impact of courtyard aspect ratio on each building geometries being observed. When the courtyard aspect ratio increases from 1:1 to 1:2, H geometries' annual cooling energy decreases in three different orientations simulated. For $\mathrm{H}$ geometry, the highest annual cooling energy reduction is when changing the courtyard aspect ratio of $\mathrm{H}$ geometry elongated alongside the west-east axis. H geometry's annual cooling energy elongated alongside the west-east axis with a courtyard aspect ratio of 1:1 would decrease $3.63 \mathrm{kWh} / \mathrm{m} 2 \mathrm{yr}$ when the courtyard aspect ratio is changed to 1:2. 

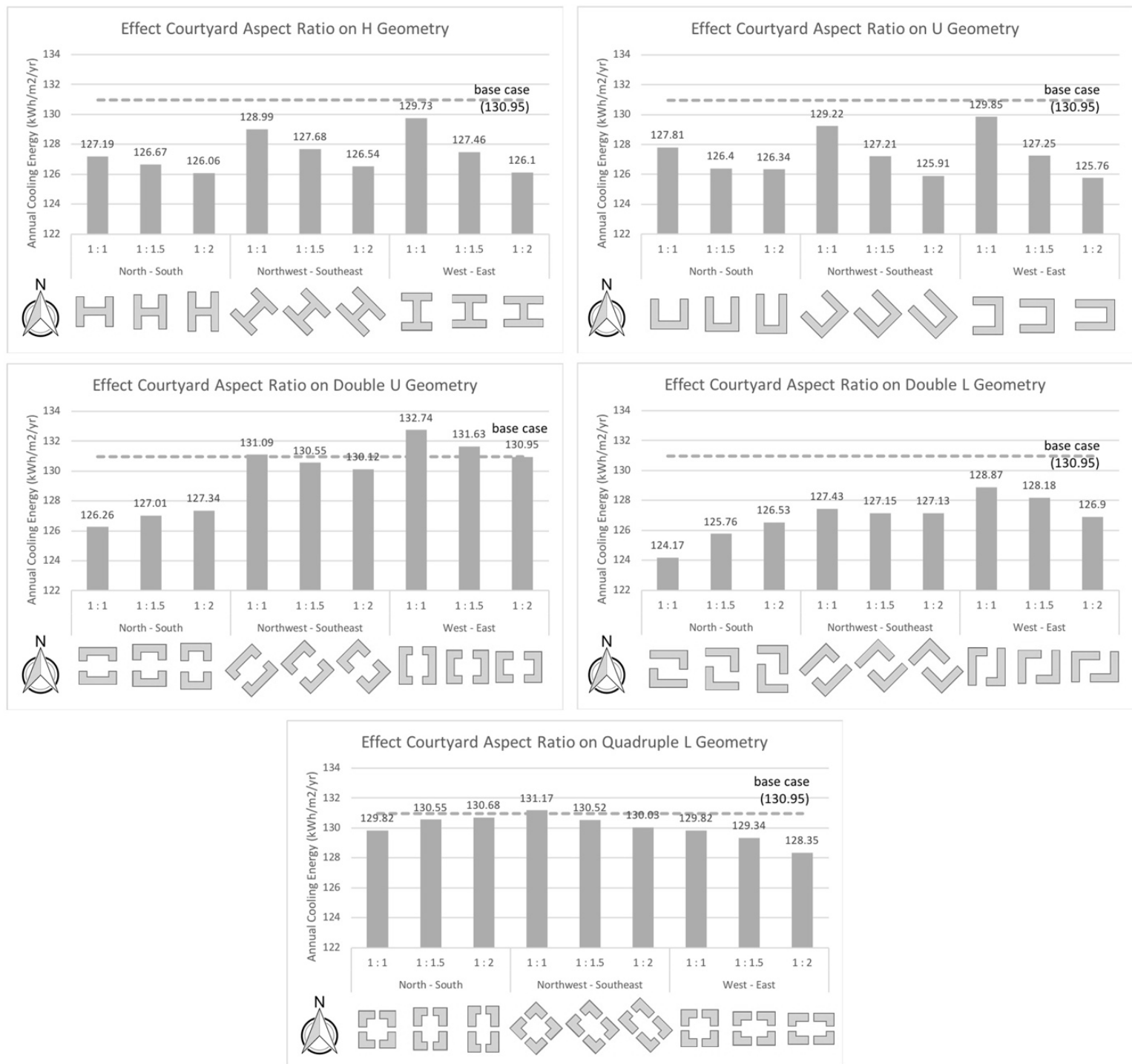

FIGURE 4 The impact of courtyard aspect ratio on each building geometries being observed.

Similar to $\mathrm{H}$ geometry, when the courtyard aspect ratio increases from 1:1 to 1:2, U geometries' annual cooling energy decreases in three different orientations simulated. For U geometry, the highest annual cooling energy reduction is when changing the courtyard aspect ratio of $U$ geometry elongated alongside the west-east axis. $U$ geometry's annual cooling energy elongated alongside the west-east axis with a courtyard aspect ratio of $1: 1$ would decrease $4.09 \mathrm{kWh} / \mathrm{m} 2 \mathrm{yr}$ when the courtyard aspect ratio is changed to $1: 2$.

For Double U geometry, when the building is elongated alongside the west-east and northwest-southeast axis, changing the courtyard aspect ratio from 1:1 to $1: 2$ would reduce the annual cooling energy of the building by $0.97 \mathrm{kWh} / \mathrm{m} 2 \mathrm{yr}$ and 1.79 $\mathrm{kWh} / \mathrm{m} 2 \mathrm{yr}$, respectively. On the other hand, when the building is elongated alongside the north-south axis, annual cooling energy would increase $1.08 \mathrm{kWh} / \mathrm{m} 2 \mathrm{yr}$.

Changing the courtyard aspect ratio from 1:1 to 1:2 of Double L geometry when the building is elongated alongside the westeast and northwest-southeast axis would reduce the building's annual cooling energy $0.3 \mathrm{kWh} / \mathrm{m} 2 \mathrm{yr}$ and $1.97 \mathrm{kWh} / \mathrm{m} 2 \mathrm{yr}$, respectively. Changing the courtyard aspect ratio from 1:1 to 1:2 of Double L geometry when the building is elongated alongside the north-south axis would increase annual cooling energy by $2.36 \mathrm{kWh} / \mathrm{m} 2 \mathrm{yr}$. 
TABLE 3 Detailed material input of the model experiment.

\begin{tabular}{lclll}
\hline Geometry & $\begin{array}{c}\text { Courtyard } \\
\text { L/W }\end{array}$ & \multicolumn{3}{l}{ Annual Cooling Energy $(\mathbf{k W h} / \mathbf{m} 2 / \mathbf{y r})$} \\
& 1 & 127.19 & $\mathbf{N W - S E}$ & $\mathbf{W}-\mathbf{E}$ \\
\hline $\mathrm{H}$ & 1.5 & 126.67 & 128.99 & 129.73 \\
& 2 & 126.06 & 126.54 & 127.46 \\
$\mathrm{U}$ & 1 & 127.81 & 129.22 & 126.10 \\
& 1.5 & 126.40 & 127.21 & 127.85 \\
Double U & 2 & 126.34 & 125.91 & 125.76 \\
& 1 & 126.26 & 131.09 & 132.74 \\
Double L & 1.5 & 127.01 & 130.55 & 131.63 \\
& 2 & 127.34 & 130.12 & 130.95 \\
& 1 & 124.17 & 127.43 & 128.87 \\
Quadruple L & 1.5 & 125.76 & 127.15 & 128.18 \\
& 2 & 126.53 & 127.13 & 126.90 \\
& 1 & 129.82 & 131.17 & 129.82 \\
& 1.5 & 130.55 & 130.52 & 129.34 \\
& 2 & 130.68 & 130.03 & 128.35 \\
\hline
\end{tabular}

Similar to Double U and Double L Geometries, when Quadruple L Geometry is elongated alongside the west-east and northwestsoutheast axis, changing the courtyard aspect ratio $1: 1$ to $1: 2$ would reduce annual cooling energy of $1.14 \mathrm{kWh} / \mathrm{m} 2 \mathrm{yr}$ and 1.47 $\mathrm{kWh} / \mathrm{m} 2 \mathrm{yr}$, respectively. On the other hand, when the building is elongated alongside the north-south axis, annual cooling energy would increase about $0.86 \mathrm{kWh} / \mathrm{m} 2 \mathrm{yr}$.

In general, a courtyard with an aspect ratio of 1:2 results in lower annual cooling energy of buildings. The influence of courtyard $\mathrm{L} / \mathrm{W}$ is more significant on $\mathrm{H}$ and $\mathrm{U}$ geometries when the building is elongated alongside the west-east axis, reducing cooling energy consumption up to $3.63 \mathrm{kWh} / \mathrm{m} 2 \mathrm{yr}$ and $4.09 \mathrm{kWh} / \mathrm{m} 2 \mathrm{yr}$, respectively. For Double U, Double L, and Quadruple L Geometries, the impact of changing the courtyard aspect ratio from 1:1 to 1:2 is not as significant as $\mathrm{H}$ and U Geometries because the change of annual cooling energy range from $0.3-1.97 \mathrm{kWh} / \mathrm{m} 2 \mathrm{yr}$.

As seen in Table 3, although a courtyard with an aspect ratio of 1:2 results in lower annual cooling energy of buildings, there are some cases where a longer courtyard result in higher energy consumption. Increasing courtyard length of Double U, Double L, and Quadruple L geometries with north-south orientation could increase cooling energy consumption up to 1.08, 2.36, and $0.86 \mathrm{kWh} / \mathrm{m} 2 \mathrm{yr}$, respectively. In addition, the effect of higher courtyard L/W is not significant on double L geometry oriented to northwest-southeast, which could reduce the cooling energy consumption by only about $0.3 \mathrm{kWh} / \mathrm{m} 2 \mathrm{yr}$.

\section{2 | Discussion}

Unlike $\mathrm{H}$ and $\mathrm{U}$ geometries, an increase of courtyard aspect ratio results in lower energy consumption for all orientations, Double U, Double L, and Quadruple L geometries north-south orientation. A higher courtyard aspect ratio results in more cooling energy consumption. This phenomenon results from the courtyard gaps present in Double U, Double L, and Quadruple L geometries facing the east and west sides, allowing the solar radiation to penetrate the courtyard area, diminishing the shading impact created by the courtyard area. Although $\mathrm{U}$ and $\mathrm{H}$ geometries also have courtyard openings, the open-ended courtyards face north and south, similar to the building orientation. Courtyard of $\mathrm{H}$ and $\mathrm{U}$ geometries, which faces south and north, receive less solar radiation than courtyard with the opening facing west or east.

To further understand the heat gain and cooling load of the model experiments, elementals breakdowns from the effect of elongating the courtyard in model experiments are studied. As shown in Fig 5, the elemental breakdown of $\mathrm{H}$ and $\mathrm{U}$ Geometries are investigated when the building is elongated alongside the west-east axis because elongating the courtyard in this orientation would result in the highest reduction of annual cooling energy. As shown in Fig 6, for Double U, Double L, and Quadruple Geometries, these geometries' elemental breakdowns are investigated when the building is elongated alongside the north-south axis. Elongating the courtyard of Double U, Double L, and Quadruple Geometries on north-south orientation would increase energy consumption. Therefore it should be investigated.

According to both elemental breakdown of $\mathrm{H}$ and $\mathrm{U}$ geometries, sensible cooling load decreases when solar gain decrease. In the case of $U$ geometry, although fabric and infiltration gain increase when the courtyard aspect ratio is increased from 1:1 to $1: 2$, the sensible cooling load remains decreasing. In addition, the latent cooling load in both geometries decreases when the 


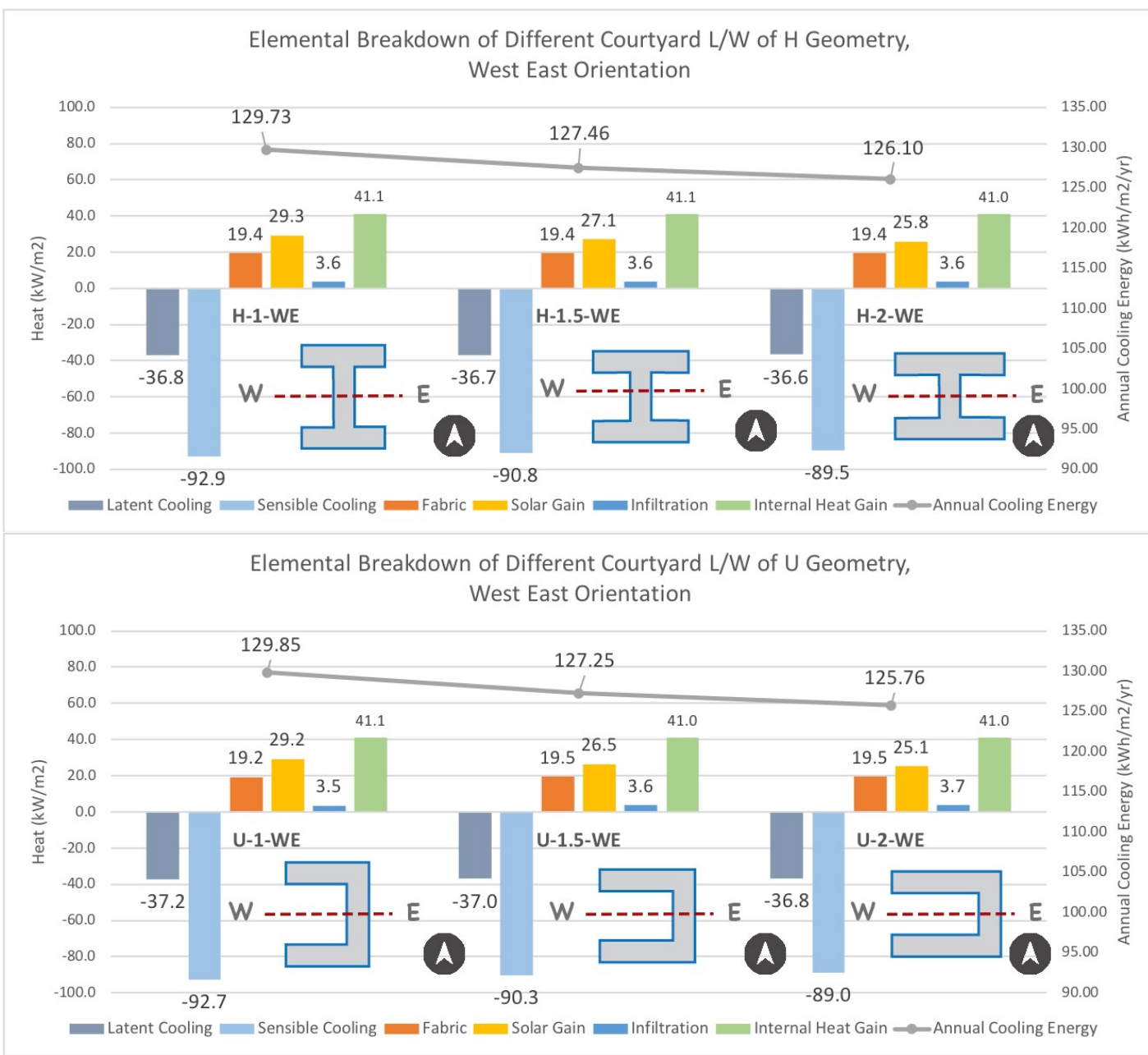

FIGURE 5 Elemental breakdown of $\mathrm{H}$ and $\mathrm{U}$ geometries.

courtyard is elongated, resulting in a lower total cooling load because annual cooling energy is the sum of latent and sensible cooling load. Based on this analysis, the reduction of $\mathrm{H}$ and $\mathrm{U}$ geometries' annual cooling energy, when the courtyard aspect ratio is increased from 1:1 to $1: 2$, is mainly caused by decreasing solar heat gain factor. The study of $\mathrm{U}$ and $\mathrm{H}$ geometry verify the study by Muhaisen and Gadi ${ }^{[8}$, which stated that a square-shaped courtyard generates a higher cooling load than a rectangular courtyard. This study also mentioned that solar radiation caused the rectangular courtyard to generate a higher cooling load. In addition, Almhafdy et al. ${ }^{91}$ stated that a U-shaped courtyard with an aspect ratio of 1:2 is better than a courtyard with an aspect ratio of $1: 1$.

When the courtyard aspect ratio increases from 1:1 to 1:2 of Double $\mathrm{U}$ geometry on north-south orientation increases the annual cooling energy of $1.08 \mathrm{kWh} / \mathrm{m} 2 / \mathrm{yr}$, and on west-east orientation decreases annual cooling energy of $1.79 \mathrm{kWh} / \mathrm{m} 2 / \mathrm{yr}$. When the building is elongated alongside the west-east axis, increasing the courtyard aspect ratio increases from 1:1 to 1:2 of Double $\mathrm{U}$ geometry would decrease the solar gain and infiltration gain about $1.6 \mathrm{~kW} / \mathrm{m} 2$ and $0.3 \mathrm{~kW} / \mathrm{m} 2$, respectively. Although the fabric gain increases $(0.7 \mathrm{~kW} / \mathrm{m} 2)$, the sensible cooling load still decreases, because according to the regression analysis, solar gain and infiltration gain have a higher relationship than fabric gain. Latent cooling energy also decreasing when the courtyard of Double $\mathrm{U}$ is elongated on the west-east orientation. On the other hand, increasing the courtyard aspect ratio is increased from 1:1 to 1: 2 of Double U geometry on north-south orientation would increase both solar gain and infiltration gain, thus increase the sensible cooling load. When infiltration gain increases, latent cooling load tend to increase also.

Similar to Double U geometry, increasing courtyard aspect ratio is increased from 1:1 to 1: 2 of Double L and Quadruple L geometries on the west. East orientation would increase the fabric gain but decrease solar gain and infiltration gain. The solar 

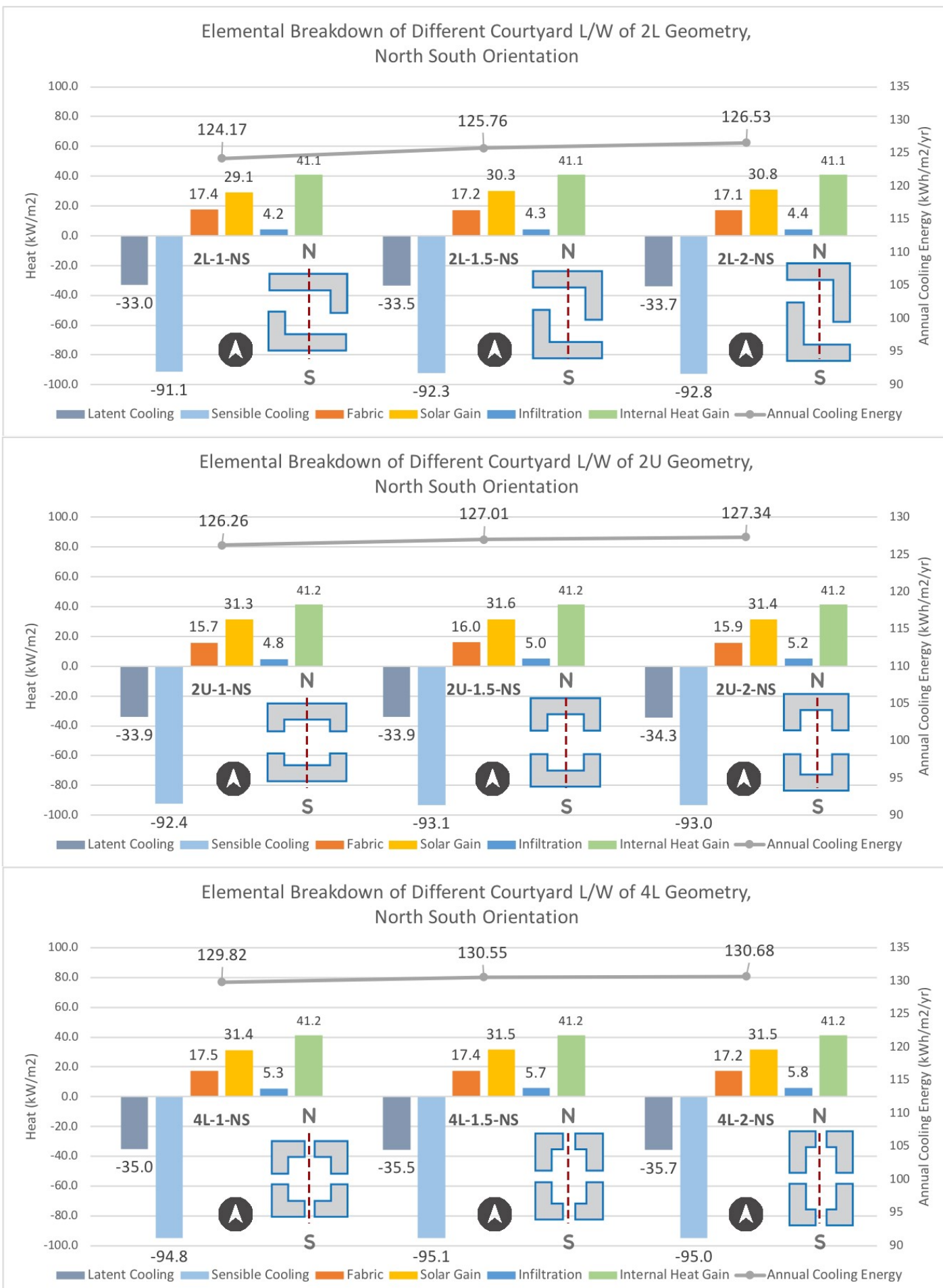

FIGURE 6 Elemental breakdown of double U, double L, and quadruple L geometrie.

gain of Double L geometry decreases $0.2 \mathrm{~kW} / \mathrm{m} 2$, and infiltration gain decreases $0.4 \mathrm{~kW} / \mathrm{m} 2$, while the solar gain of Quadruple L geometry decreases $0.9 \mathrm{~kW} / \mathrm{m} 2$ and infiltration gain decreases $0.8 \mathrm{~kW} / \mathrm{m} 2$. Decreasing the amount of solar and infiltration gain results in a lower sensible cooling load. The differences of increasing courtyard aspect ratio are increased from 1:1 to 1:2 of Double L and Quadruple L geometries on west-east orientation is the amount of latent cooling load. For Double L geometry elongating the courtyard would result in a lower latent cooling load of $0.6 \mathrm{~kW} / \mathrm{m} 2$. On the other hand, the latent cooling load 
of Quadruple L geometry increases $0.4 \mathrm{~kW} / \mathrm{m} 2$ and $0.2 \mathrm{~kW} / \mathrm{m} 2$ when the courtyard aspect ratio is $1: 1.5$ and $1: 2$, respectively, compared with courtyard L/W of 1 . Although Quadruple L geometry's latent cooling load slightly increases, the annual cooling load of Quadruple L geometry decreases because the effect from decreasing sensible cooling load is higher than increasing latent cooling load.

The cause of increasing annual cooling energy of Double L and Quadruple L geometries, when the courtyard aspect ratio is increased from 1:1 to 1: 2 on north-south orientation is similar with Double $\mathrm{U}$ geometry, which is a higher value of both latent and sensible cooling load. Increasing the courtyard aspect ratio is increased from 1:1 to 1: 2 of Double L and Quadruple L geometries on north-south orientation would decrease the fabric gain but increase solar gain and infiltration gain. The solar gain of Double L geometry increases $0.9 \mathrm{~kW} / \mathrm{m} 2$, and infiltration gain increases $0.2 \mathrm{~kW} / \mathrm{m} 2$, while the solar gain of Quadruple L geometry increases $0.1 \mathrm{~kW} / \mathrm{m} 2$ and infiltration gain increases $0.5 \mathrm{~kW} / \mathrm{m} 2$. The latent Cooling load of both geometries also increases $0.7 \mathrm{~kW} / \mathrm{m} 2$.

The finding verifies Muhaisen and Gadi's study ${ }^{[8}$, which mentioned that rectangular courtyard generates lower cooling energy than square one. The model experiments' elemental breakdown shows that longer courtyards have a lower sensible cooling load caused by a smaller solar heat gain value. Although the Study of Muhaisen and Gadi (2006) is conducted in a temperate climate, the result also applied in the warm and humid equatorial region. In addition, the impact of courtyard opening also verifies the study by Almhafdy et al. ${ }^{[10}$, which stated that surfaces next to the courtyard opening have higher temperatures because of solar radiation.

\section{4 | CONCLUSION}

The result reveals that a courtyard with an aspect ratio of 1:2 tends to perform better than a square courtyard. Elongating the courtyard of $\mathrm{H}$ and $\mathrm{U}$ Geometry would reduce the annual cooling energy in all orientations. Elongating the courtyard of Double U, Double L, and Quadruple L Geometries would reduce the annual cooling energy in northwest-southeast orientation and increase annual cooling energy if the building is elongated alongside the northeast axis.

Lower annual cooling energy consumption when elongating the courtyard is mainly caused by lower solar heat gain that penetrates the building. Lower solar heat gain would result in a lower sensible cooling load of a building. On the other hand, increasing annual cooling energy consumption when elongating the courtyard of Double U, Double L, and Quadruple L Geometries is caused by higher solar heat gain and latent heat gain. This condition is caused by these geometries' courtyard gaps, which allows solar radiation to penetrate the courtyard.

\section{References}

1. Salanto F, Gobi R, Salanto F, editor, Colliers I Property Market Report I H2 2020 I Surabaya All Sector. Cooliers International; 2020. https://www2.colliers.com/en-id/research/ colliers-quarterly-property-market-report-h2-2020-surabaya-all-sector

2. Alfata MNF, Hirata N, Kubota T, Nugroho AM, Uno T, Ekasiwi SNN, et al. Field investigation of indoor thermal environments in apartments of Surabaya, Indonesia: Potential passive cooling strategies for middle-class apartments. Energy Procedia 2015;78:2947-2952.

3. Suheta T, Huda MF. AUDIT PENGGUNAAN ENERGI LISTRIK PADA APARTMENT METROPOLIS SURABAYA. In: Seminar Nasional Sains dan Teknologi Terapan V Surabaya: Institut Teknologi Adhi Tama Surabaya; 2017. p. 91-98. https://conference.itats.ac.id/index.php/sntekpan/2017/paper/viewFile/92/88

4. Yeang K. The Green Skyscraper: The Basis for Designing Sustainable Intensive Buildings: Ken Yeang: 9783791319933: Amazon.com: Books. 1st ed. New York: Prestel Publishing; 2000. https://www.amazon.com/ Green-Skyscraper-Designing-Sustainable-Intensive/dp/3791319930

5. Aldawoud A, Clark R. Comparative analysis of energy performance between courtyard and atrium in buildings. Energy and Buildings 2008;40(3):209-214. 
6. Zakaria MA, Kubota T. Environmental Design Consideration for Courtyards in Residential Buildings in Hot-humid Climates: A Review. International Journal of Built Environment and Sustainability 2014;1(1).

7. Lewis E, Lewis E. Climate Responsive Design. In: Sustainaspeak, 1st ed. New York: Routledge; 2018.p. 61-63.

8. Maniolu G, Oral GK. Effect of courtyard shape factor on heating and cooling energy loads in hot-dry climatic zone. Energy Procedia 2015;78:2100-2105.

9. Almhafdy A, Ibrahim N, Ahmad SS, Yahya J. Thermal Performance Analysis of Courtyards in a Hot Humid Climate Using Computational Fluid Dynamics CFD Method. Procedia - Social and Behavioral Sciences 2015;170:474-483.

10. Muhaisen AS, Gadi MB. Effect of courtyard proportions on solar heat gain and energy requirement in the temperate climate of Rome. Building and Environment 2006;41(3):245-253.

How to cite this article: Dewi P.M., Antaryama I.G.N., Ima Defiana (2021), Effect of Courtyard Aspect Ratio on Annual Cooling Energy of Highrise Apartment in Surabaya, IPTEK The Journal of Technology and Science, 31(3):269-278. 